active. The cornea measured $16.5 \mathrm{~mm}$. in diameter and showed diffuse and linear opacities, the centre was clear. The child would not permit of a corneal microscope examination, or the consistence of the fluid in the chamber might have been determined. The prognosis in this case is bad. In neither of the successful cases above recorded was the character of the aqueous fluid altered. The zonule presumably had not been so damaged by stretching as to allow of the vitreous (probably in such cases more fluid than normal), invading the anterior segment and mingling with the aqueous. After the removal of V's left eye (Case 1), when a fine radial cut was made through the cornea to allow better penetration of the fixative, a thin watery vitreous escaped. Evidently, since his previous vișit to the hospital the zonule had become stretched and torn and the integrity of vitreous and aqueous interfered with. The success or failure of an anterior decompression must very largely depend on whether the normal relationship of aqueous and vitreous is preserved; and the changes which result in the zonule, and the vitreous body itself, as a result of stretching of the globe, eventually upset this relationship.

\title{
ANNOTATIONS
}

\section{Mr. Priestley Smith's Inaugural Address}

"For this do I honour my own profession." Religio Medici, 1, 13.

Those who have been so fortunate as to see the number of the Birmingham Medical Review for the month of October, 1930, must have thoroughly enjoyed reading the inaugural address, to the students in the medical faculty, delivered by Emeritus Professor Priestley Smith, LL.D., the doyen of British Ophthalmology. After commenting on his rashness in addressing a large concourse of students twenty years after the date of his retirement from active professorial work, Mr. Priestley Smith gives some interesting details of his own career as a student; comments in a delightful manner on what must surely be endemic among boys who have just left school, viz., " no urgent desire for further work of any kind"; recalls how he began life as an engineer, in which profession he served a four years' apprenticeship; how he took up medicine, later in life than the average medical student, when he was nearly twenty-two years of age; and finally how he has never regretted his choice of a profession.

His address followed on customary lines and contains much good advice to those who are entering the medical profession. We 
feel sure that those who were privileged to hear it must have left the theatre imbued with the highest ideals of life in a profession, which is above all others, altruistic, as set out by a much beloved master, whose life and work should be an inspiration to all medical students.

\section{Intracapsular Extraction}

The battle between intracapsular extraction of cataract and extraction with capsulotomy, and subsequent needling if necessary, has been waged for some years past. The policy of this journal has always been not to take sides in this matter. We admit that for the Indian peasant a single operation has its advantage; but in this matter, "East is east and West is west," and the advocates of the Indian operation must allow the majority of surgeons in England to go on in the old-fashioned manner until it has been shown that the operation, in the hands of the average English surgeon, is as safe as the older methods have been proved to be. The enormous operative experience of Indian surgeons is admitted. In this country probably no surgeon has the opportunity of performing a tithe of the number of extractions performed in the big Indian centres in the course of a single year.

The paper by Dr. Conor O'Malley in the current number raises the question anew; in it he is mainly concerned with the method of lens delivery per se; he considers that as it is comparatively successful in spite of conditions which would seem to militate against it, it must have some intrinsic merit.

Our readers may possibly take exception to certain points, such as the entire lack of bacteriological examination of the field of operation prior to the extraction; the fact that two eyes are operated on, if need be, at a single sitting; and that some lenses, apparently with very little opacity as seen after extraction, were removed. With regard to this last point the author admits that his statement is liable to misconstruction; he saw no transparent lens, or one with incipient cataract extracted; he wishes to emphasise the fact that it is not necessary to wait for maturity in cases where the opacity is causing serious defects of vision.

The operating season in a rural clinic in India such as the one he worked in is only of about five weeks' duration; there are only one surgeon and three qualified assistants. Patients come in hundreds and if they are not operated on at once, they leave, never to return. Were bacteriological examination attempted as a routine it would mean that 90 per cent. of cases would return to their homes without any operation at all.

It will be seen that conditions in a rural clinic in India cannot be compared with those in this country; we should think that visual 